\title{
Urethral Gel Dosage Form
}

National Cancer Institute

\section{Source}

National Cancer Institute. Urethral Gel Dosage Form. NCI Thesaurus. Code $C 91195$.

A gel intended for administration into the urethra. 